\title{
OTOLITH MICROCHEMISTRY INDICATES UNEXPECTED PATTERNS OF RESIDENCY AND ANADROMY IN BLUEBACK HERRING, ALOSA AESTIVALIS, IN THE HUDSON AND MOHAWK RIVERS.
}

\author{
K.E. LIMBURG (1), I. BLACKBURN (1), R. SCHMIDT (2), T. LAKE (2), J. HASSE (3), \\ M. ELFMAN (4), P. KRISTIANSSON (4)
}

(1) College of Environmental Science \& Forestry, State University of New York, Syracuse, NY USA.

(2) Hudsonia Ltd., Annandale-on-Hudson, NY USA.

(3) New York State Department of Environmental Conservation, Utica, NY USA.

(4) Department of Nuclear Physics, Lund University, LUND, Sweden.

Reçu le 30 septembre 2000

Accepté le 17 janvier 2001

Received 30 September, 2000

Accepted 17 January, 2001

\begin{abstract}
Blueback herring is an anadromous fish endemic in the tidal Hudson River Estuary, USA. Twentieth-century improvements to a lock and canal system permitted the species to invade the Hudson's main tributary, the Mohawk River, where it has been recorded since the 1930s. Moving westward over time, individuals were collected in Lake Ontario, approx. $275 \mathrm{~km}$ west of the Hudson, in 1997. However, the actual status (resident or marine anadromous) of adults there or in the Mohawk has not been determined. We collected adult blueback herring in the spring 1999 spawning run and analyzed their otoliths' elemental composition with both electron (WDS) and nuclear ( $\mu$ PIXE) microprobes. We measured strontium:calcium ratios along "life-history transects " (WDS) and mapped entire otoliths ( $\mu \mathrm{PIXE}$ ), providing a detailed time series of data on the $\mathrm{Sr}: \mathrm{Ca}$, and thus habitat use history, of the fish. We also analyzed otoliths of Mohawk and Hudson River young-of-year (YOY). The Sr:Ca ratios of Mohawk YOY are slightly but significantly higher than those of Hudson YOY. Life history transects for 51 adults show complex patterns of $\mathrm{Sr}: \mathrm{Ca}$, indicating that many of the fish move into salt water at least for brief periods. However, many fish appear to spend extended parts of their post-YOY lives in fresh water, and at least two adults (caught in the Mohawk near Rome, NY) appear never to have changed habitats at all. This is thus the first demonstration of residency in Mohawk River herring.
\end{abstract} history.

Key-words : Alosa aestivalis, landlocking, otolith microchemistry, environmental 


\section{LA MICROCHIMIE DES OTOLITHES RÉVÈLE DES MODĖLES INATTENDUS DE COMPORTEMENT SÉDENTAIRE ET ANADROME DE L'ALOSE D'ÉTÉ, ALOSA AESTIVALIS, DANS LES RIVIĖRES HUDSON ET MOHAWK.}

\section{RÉSUMÉ}

L'alose d'été, poisson anadrome endémique de la rivière Hudson, Etats-Unis, a été observée sur un affluent, la rivière Mahawk, depuis les années 1930. Se déplaçant continuellement vers l'ouest, des individus ont été capturés dans le lac Ontario, en 1997. Toutefois, le véritable statut (sédentaire ou anadrome marin) des adultes du lac Ontario ou de la rivière Mohawk n'a pas été déterminé. Nous avons capturé des aloses d'été adultes au printemps 1999, lors de la migration de reproduction et nous avons analysé la composition élémentaire de leurs otolithes à la fois à l'aide de micro-sondes à électrons (WDS) et de micro-sondes nucléaires ( $\mu$ PIXE). Nous avons mesuré le rapport strontium/calcium $(\mathrm{Sr} / \mathrm{Ca})$ le long de transects d'histoire de vie (WDS) et photographié entièrement les otolithes ( $\mu \mathrm{PIXE}$ ), ce qui a permis de recueillir des données détaillées sur les séries temporelles, concernant le rapport $\mathrm{Sr} / \mathrm{Ca}$, et aussi sur l'histoire de vie en relation avec la salinité. Nous avons aussi analysé des otolithes de juvéniles (YOY) des rivières Hudson et Mohawk. Le rapport $\mathrm{Sr} / \mathrm{Ca}$ des juvéniles de Mohawk est légèrement mais significativement plus élevé que pour ceux de l'Hudson. Les coupes de l'histoire de la vie de 51 adultes montrent des patrons complexes de $\mathrm{Sr} / \mathrm{Ca}$, montrant que beaucoup de poissons vont en eau salée au moins pendant de brèves périodes. Cependant, beaucoup de poissons semblent passer de longues périodes de leur vie post-juvénile en eau douce, et au moins deux adultes (capturés dans la rivière Mohawk près de Rome, NY) paraissent ne jamais avoir changé d'habitat. C'est donc la première démonstration de sédentarité des aloses d'été dans la rivière Mohawk.

Mots-clés : Alosa aestivalis, sédentarité en eau douce, microchimie des otolithes, histoire environnementale.

\section{INTRODUCTION}

Blueback herring (Alosa aestivalis) is an anadromous clupeid ranging from the St. Lawrence River in Canada to the Carolinas in the United States. In the Hudson River Estuary in New York State, it is one of the key fish components of the upper, tidal estuary, both numerically and in terms of biomass. The Mohawk River is the largest tributary of the Hudson (Figure 1). Historically, waterfalls obstructed the movement of fish upstream, but construction of the Erie Lock and Canal system enabled fish to move from the Hudson into the Mohawk (GREELEY, 1935). Over the past twenty years or so, a progressive, westward movement of blueback herring spawning activity has been noted in the Mohawk River and connected water bodies, and fish were recently discovered in Lake Ontario some $275 \mathrm{~km}$ west of the Hudson (OWENS et al., 1998 ; MACNEILL, 1998).

Blueback herring have established landlocked populations in the southeastern U.S. The reported populations were established either through accidental introduction (PRINCE and BARWICK, 1981) or by becoming trapped behind dams (e.g., ISELY and TOMASSO, 1998). The movement of bluebacks up into the Mohawk, via the New York State lock and canal system, is a previously unreported volitional range expansion, and is therefore potentially unique. Furthermore, there is a consensus that if blueback herring can survive in Lake Ontario, they will be able to spread into the other Great Lakes and into the Mississippi drainage (MACNEILL, 1998).

The purpose of this study was to conduct preliminary investigations of adult fish in the Mohawk and Hudson Rivers, to determine whether fish were undergoing anadromous 
migrations or had begun to establish freshwater residency. We used the method of analyzing strontium to calcium ratios in otoliths (see CAMPANA 1999 for description) where increasing Sr:Ca correlates with increasing salinity. Microanalysis of $\mathrm{Sr}: \mathrm{Ca}$ along transects in otoliths serves as a means to trace environmental histories of individual fish. This method has been used to study the movements of many diadromous species (e.g., eels Anguilla spp. (CASSELMAN, 1982 ; TZENG, 1996 ; TSUKAMOTO et al., 1998), striped bass Morone saxatilis (SECOR and PICCOLI, 1996), salmonids (KALISH, 1990), and American shad Alosa sapidissima (LIMBURG, 1995)), and has been cross-validated in Alosa spp. (including blueback herring) by means of stable isotope analysis (LIMBURG, 1998).

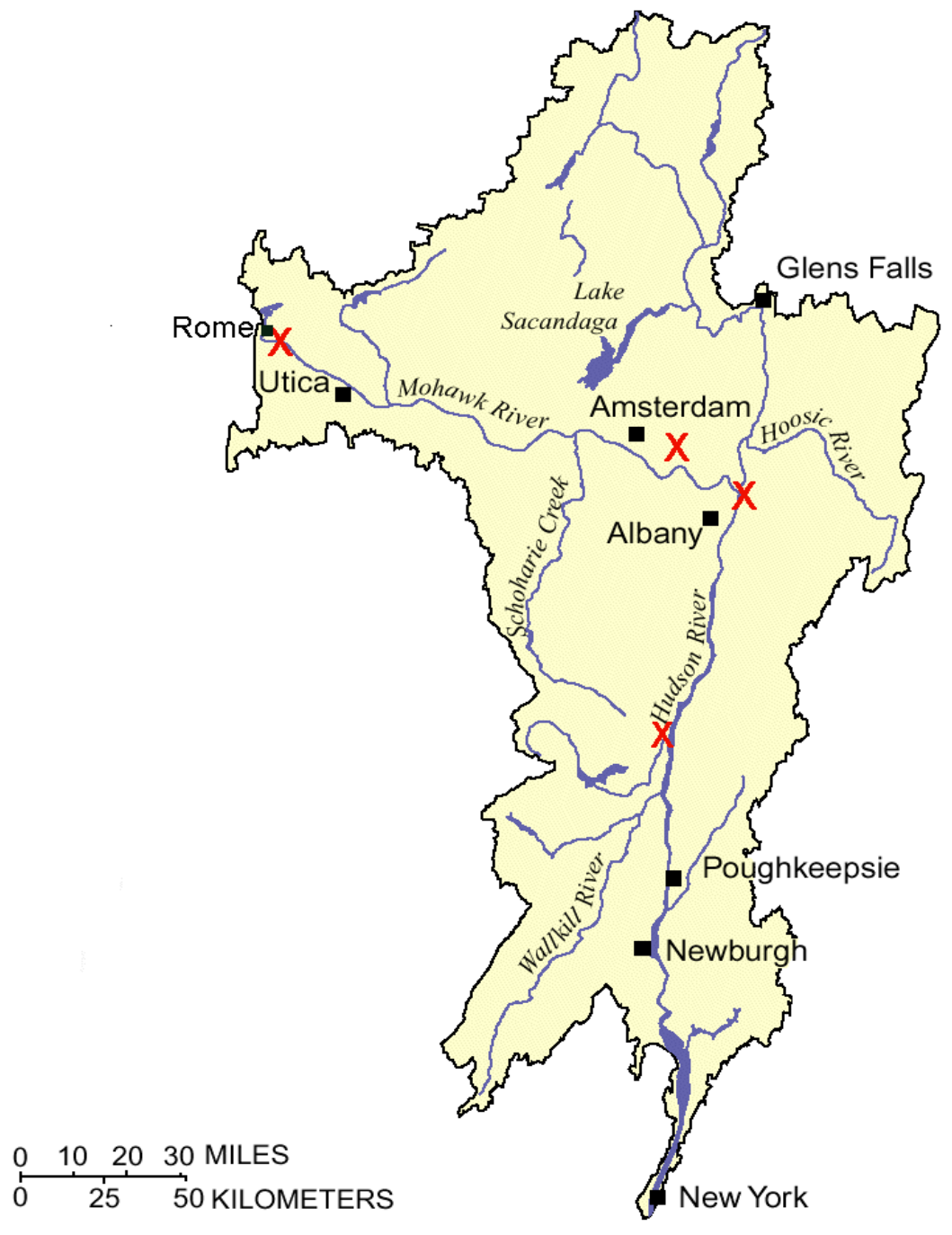

\section{Figure 1}

Map of the Hudson-Mohawk drainage basin. Sampling locations are indicated by « $X$ » marks.

\section{Figure 1}

Carte du bassin des rivières Hudson-Mohawk. Les lieux de prélévement sont indiqués par des marques « $X$ ».

MATERIAL AND METHODS 
Fifty-one adult fish were collected during the 1999 spawning run at 4 sites in the Mohawk and Hudson Rivers (Figure 1), measured, and stored frozen. Sagittal otoliths were removed, mounted on glass slides, and ground and polished to expose the core. Age was determined by counting annual rings in the otolith ; the formation of an annual increment (opaque plus translucent zones) was verified in yearling fish (LIMBURG, unpublished data). $\mathrm{Sr}$ and $\mathrm{Ca}$ were analyzed along a transect from the otolith core to the outer edge, using a wavelength dispersive (WDS) electron microprobe (see LIMBURG, 1995 for analytic details). To verify transect patterns, otoliths from 6 of these fish were re-analyzed spatially with a nuclear microprobe coupled with proton-induced X-ray spectroscopy ( $\mu$ PIXE ; see ELFMAN et al., 2000 for analytic details). Finally, life-history transects were made on otoliths of several young-of-year fish in the Hudson and Mohawk Rivers (five fish in each river) ; young-of-year fish are presumed to be non-migratory, and so the Sr:Ca in their otoliths should reflect the environmental signal from the river of capture.

\section{RESULTS}

Adult fish displayed an unexpectedly wide variety of movement behaviors as indicated by the $\mathrm{Sr}$ :Ca ratios in their otoliths. Among these, several behaviors are typified in Figure 2. A few fish demonstrated " classic anadromy » (Figure 2a), that is, migration to sea after the $1^{\text {st }}$ growing season and return to spawn. Figure $2 \mathrm{~b}$ shows a fish that moved out its first winter, returned to the Hudson as a yearling, moved out to sea its second winter, then moved into brackish water. Fish collected farthest west in Rome, NY, were significantly smaller than males collected down in the Hudson, and both growth increment patterns and Sr:Ca levels varied substantially. An otolith transect from a male collected there (Figure 2c) does not show any major change in movement - rather, a meandering at moderately high Sr:Ca levels. 

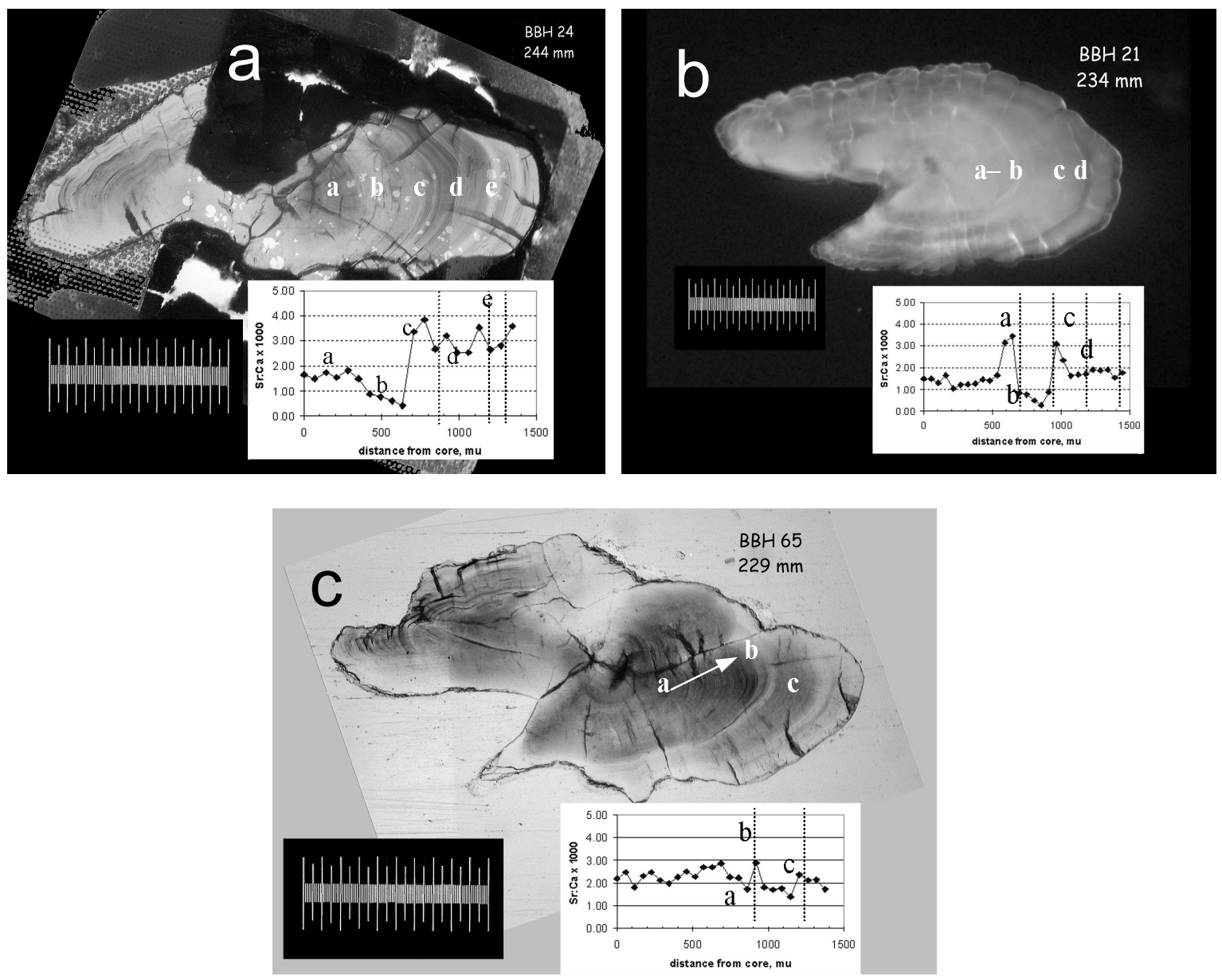

Figure 2

Patterns of otolith Sr:Ca measured by WDS microprobe analysis, compared with photomicrographs of otoliths from these individual fish. Dotted lines on the graphs represent formation of annuli, and letters on the graphs and micrographs show corresponding areas of interest. (a) A female (age 4+) collected 9 June, 1999 in the lower Mohawk River ; transmitted light (otolith was subjected to both WDS and $\mu$ PIXE analysis). Note the false annulus at point ' $d$ '. (b) A female (age $4+$ ) collected as in (a) ; reflected light (otolith is the mate of the one that was analyzed). (c) A male (age 3+) collected at Rome on 23 June 1999 ; transmitted light (otolith was subjected only to WDS analysis ; some areas were ground away to expose the core and posterior, as is true of the specimen in (a) as well). The scale is $1.0 \mathrm{~mm}$. Note that translucent zones appear bright in transmitted light and dark in reflected light.

\section{Figure 2}

Rapports $\mathrm{Sr} / \mathrm{Ca}$ des otolithes mesurés par des analyses par microsondes WSD. L'axe X représente un transect de la partie postérieure de l'otolithes et traversant toutes les annuli. (a) Anadromie : d'abord une basse valeur du rapport $\mathrm{Sr} / \mathrm{Ca}$ suivi par une brusque élévation qui se maintient ; (b) mouvement de l'eau douce vers la mer et inversement ; (c) suivi du rapport $\mathrm{Sr} / \mathrm{Ca}$ chez un mâle pris à Rome NY et montrant une valeur constante du rapport dans tout l'otolithe. 
The WDS analyses indicated that Sr levels appeared somewhat higher, and $\mathrm{Ca}$ levels lower, in fish collected in the Mohawk vs in the Hudson. A comparison of Sr:Ca ratios in young-of-year, more-or-less stationary fish from both systems indicated that this difference was significant (repeated measures ANOVA, $p<0.01$; STATSOFT, 1999).

In order to confirm the unusual patterns observed in the 51 WDS analyses, we analyzed otoliths from 6 individuals with higher-resolution $\mu$ PIXE and mapped the patterns of Sr:Ca. Four of these $\mu$ PIXE Sr:Ca maps were compared with the corresponding WDS transects (Figure 3). The correspondence is excellent, confirming the complexity of migration in these fish. The mapping analyses demonstrate elevated levels of $\mathrm{Sr}: \mathrm{Ca}$ in the interior portions of 3 otoliths - we believe this corresponds to young-of-year residency in the Mohawk River.
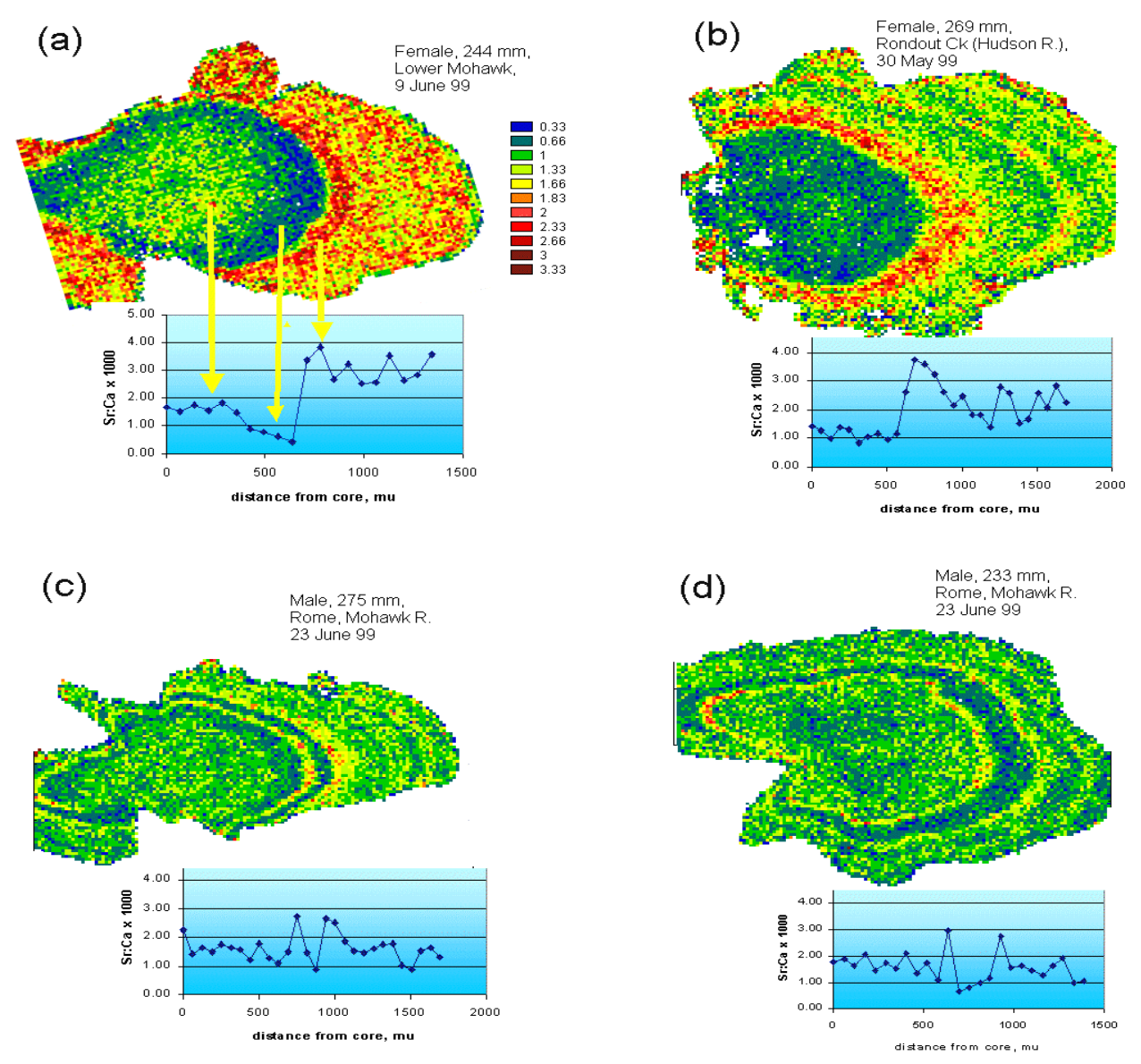

Figure 3

Comparison of WDS microprobe analyses with •PIXE Sr:Ca maps. The four images represent analyses of otoliths from four individual blueback herring. $\mu \mathrm{PIXE}$ zones corresponding to WDS zones are indicated with arrows only on image (a).

\section{Figure 3}

Comparaison des analyses microsonde avec les cartes •PIXE Sr:Ca. Les quatre images représentent des analyses d'otolithes des quatre aloses d'été. Les zones $\mu \mathrm{PIXE}$ correspondant aux zones WDS sont indiquées avec des flèches seulement sur l'image (a). 


\section{DISCUSSION}

The process by which an anadromous species, such as $A$. aestivalis, becomes landlocked (i.e., establishes a reproductive, freshwater population) can be viewed in the long term as an evolutionary occurrence, but one that is mediated in the short term by ecological factors. These factors include abiotic influences, such as the physico-chemical environment of the water bodies encountered by fish, and biotic ones such as the potential for encountering food and predators. In a life-history context (ROFF, 1992), whether a fish will adopt a new lifestyle (such as a new set of habitats over its lifetime) depends on whether or not the net benefits of the new habitat equal or exceed its former habits and habitats.

Our initial studies reveal a bewildering variety of behaviors among blueback herring in the Hudson-Mohawk combined system. Otolith annuli are unusually variable and the $\mathrm{Sr}: \mathrm{Ca}$ ratios reveal that many fish spend post-YOY time in fresh water. This has not previously been reported for anadromous blueback herring, except for observations of freshwater-resident 1+ fish reported by LIMBURG (1998). In that study, both blueback herring and alewife ( $A$. pseudoharengus) were found to have both resident and anadromous forms. As part of the Erie Lock and Canal system, the Mohawk is regulated and partially closed off from connection with the Hudson River during winter months. Thus, some of the land-locking may be due to fish not exiting the Mohawk in time before closure.

The fact that Sr:Ca ratios are elevated in the Mohawk vs the Hudson is somewhat problematic. Although we do not believe that this confounds our ability to detect seawater residency, it could confound the discrimination between Mohawk and estuarine residency. A survey, currently in progress, of water chemistry in the Hudson-Mohawk corridor should help to resolve this, but another tracer, such as carbon or nitrogen stable isotopes, may also be necessary.

\section{CONCLUSIONS}

The recent invasion of blueback herring into New York State fresh waters presents an excellent and rare opportunity to study the process of land-locking, which is of fundamental scientific interest. In the case of Mohawk River fish, there is good evidence of partial residency (i.e., fish remain in fresh water some years), and some evidence of complete residency, although further study is needed. Understanding the ecological constraints on the species is of great importance to management, and to predictions of the ultimate success it will have in establishing a broad range in inland fresh waters via the Great Lakes (an emerging issue). Further, the degree to which the population of herring in the Mohawk River interacts with the Hudson River stock may also be important in sustaining the health of the latter.

\section{ACKNOWLEDGEMENTS}

We thank the Hudson River Foundation and the Swedish Agricultural and Forestry Research Council for financial support. We also thank John HUNT, Cornell University Materials Science Center, for assistance with the WDS analyses, and two anonymous reviewers for constructive comments. 


\section{REFERENCES}

CAMPANA S.E., 1999. Chemistry and composition of fish otoliths : Pathways, mechanisms and applications. Marine Ecology Progress Series, 188, 263-297.

ELFMAN M., LIMBURG K.E., KRISTIANSSON P., SVEDÄNG H., WESTIN L., WICKSTRÖM H., MALMQVIST K., PALLON J., 2000. Complex life histories of fishes revealed through natural information storage devices : case studies of diadromous events as recorded by otoliths. Nuclear Instruments and Methods in Physics Research, B 161-163, 877-881.

GREELEY J.R., 1935. Fishes of the watershed with an annotated list. Pages 63-101 In MOORE E. (ed.). A biological survey of the Mohawk-Hudson watershed. Supplemental to the Twenty-Fourth Annual Report of the New York State Conservation Department. Albany, New York, USA.

ISELY J.J., TOMASSO J.R., 1998. Estimating fish abundance in a large reservoir by markrecapture. N. Am. J. Fish. Manage., 18, 269-273.

KALISH J.M., 1990. Use of otolith microchemistry to distinguish the progeny of sympatric anadromous and non-anadromous salmonids. Fisheries Bulletin (U.S.), 88, 657666.

LIMBURG K.E., 1995. Otolith strontium traces migratory histories of juvenile American shad, Alosa sapidissima. Marine Ecology Progress Series, 119, 25-35.

LIMBURG K.E., 1998. Anomalous migrations of anadromous herrings revealed with natural chemical tracers. Can. J. Fish. Aquat. Sci., 55, 431-437.

MACNEILL D., 1998. Research needs for the blueback herring : a new invader? Report from a workshop, 20 June 1998. New York Sea Grant (mss.).

OWENS R.W., O'GORMAN R., MILLS E.L., RUDSTAM L.G., HASSE J.J., KULIK B.H., MACNEILL D.B., 1998. Blueback herring (Alosa aestivalis) in Lake Ontario : first record, entry route, and colonization potential. J. Great Lakes Res., 24, 723-735.

PRINCE E.D., BARWICK D.H., 1981. Landlocked blueback herring in two South Carolina reservoirs : reproduction and suitability as stocked prey. N. Am. J. Fish. Manage., 1, 41-45.

ROFF D.A., 1992. The evolution of life histories. Chapman and Hall, New York.

SECOR D.H., PICCOLI P.M., 1996. Age-and sex-dependent migrations of striped bass in the Hudson River as determined by chemical microanalyses of otoliths. Estuaries, 19, 778-793.

STATSOFT., 1999. STATISTICA for Windows (Computer program manual). Statsoft, Inc. Tulsa, Oklahoma USA.

TSUKAMOTO K., NAKAI I., TESCH W.V., 1998. Do all freshwater eels migrate nature ?, 396, 635-636.

TZENG W.N., 1996. Effects of salinity and ontogenetic movements on strontium : calcium ratios in the otoliths of the Japanese eel, Anguilla japonica Temminck and Schlegel. Journal of Experimental Marine Biology and Ecology, 199, 111-122. 